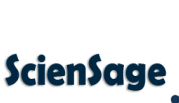

Journal of Advanced Scientific Research

Available online through https: / /sciensage.info
ISSN: 0976-9595

Research Article

DOI: $10.55218 /$ JASR. 202213127

\title{
CYTOTOXICITY AND ANTIBACTERIAL STUDIES OF NOVEL HETEROCYCLIC PYRIDINE- THIOPHENE DERIVATIVE AND ITS METAL COMPLEXES
}

\author{
Boya Rajannagari Chaitanya Kumar ${ }^{1}$, Kondra Sudhakar Babu* ${ }^{1}$ Merugu Karunasree $^{2}$ \\ ${ }^{1}$ Department of Chemistry, Sri Krishnadevaraya University, Ananthapuramu, Andhra Pradesh, India \\ ${ }^{2}$ Department of Chemistry, Gitam University, Bengaluru, Karnataka, India \\ *Corresponding author: chaitybr2@gmail.com
}

\begin{abstract}
Tranistion metals [Co, $\mathrm{Ni}$, and $\mathrm{Cu}$ ] complexes of pyridine-thiophene derivative ligand 2-((E)-2-((5-methylthiophen-2-yl) methylene)hydrazinyl)-4-methyl-6-phenylpyridine-3-carbonitrile(MTHPC) have been synthesized and characterized with different spectral investigations viz. UV-Vis, FT-IR, 1H-NMR, and ESR. The ligand and metal complexes were screened for in-vitro cytotoxicity studies against two carcinoma cell lines A549 (Lung carcinoma cells) and HepG2 (Hepatocellular carcinoma cell). The results were found to possess cytotoxic effect. Nickel complex had shown high potent cytotoxic effect for A549 cell lines and Copper complex shown high cytotoxic effect for HepG2 cell lines. The ligand and metal complexes were tested in vitro against Gram -ve bacteria such Pseudomonas desmolyticum, Escherichia coli, and Klebsiella aerogenes, as well as Gram + ve bacteria like Staphylococcus aureus. Copper and Cobalt complex has modest antibacterial action at increasing concentrations, but Nickel complex has significant antibacterial activity.
\end{abstract}

Keywords: Transition Metals, Pyridine-Thiophene derivative, Cytotoxicity studies, Antibacterial activity.

\section{INTRODUCTION}

A wide range of pharmacological actions have been related to heterocyclic compounds with pyridine rings, including anticonvulsant [1], antibacterial [2-3], antiviral [4], anticancer [5], and anti-HIV [6]. Pyridine derivatives with antifungal and anticancer characteristics have been synthesized and used as intermediates with the parent molecule 2-chloropyridine-3-carboxylic acid. $\mathrm{N}$-alkylated-2-pyridones are essential intermediates in the creation of polycyclic compounds of biological importance, according to recent synthetic techniques to anticancer [7-8] medications.

The chemistry of coordination metal complexes with nitrogen-sulphur donor ligands has recently piqued the interest of researchers, with the majority of the focus being on transition metal complexes with Schiff base ligands. The presence of both nitrogen and sulphur donor atoms in the backbones of these ligands explains this [9-10]. Schiff bases are advantageous because of their capacity to stabilize metal ions in various oxidation states, their use in a variety of catalytic and industrial applications, and their wide range of biological activities [11-13]. The lone pair of electrons of azomethine $(-\mathrm{C}=\mathrm{N}-)$ group bonding in the structure of stable metal complexes is owing to nitrogen's lone pair of electrons [14]. Current breakthroughs in the realms of bioinorganic chemistry and medicine have heightened interest in transition metal complexes with various types of ligands [15]. Due to their stability under a variety of oxidative and reductive conditions, as well as the fact that imine ligands are marginal between hard and soft Lewis bases, Schiff bases have played an important role as chelating ligands in main group and transition metal coordination chemistry over the years [16-17].

These ligands' cytotoxic effects have improved when they are coordinated with $\mathrm{Cu}$ and $\mathrm{Ni}$ ions, and they can also improve their lipophilicity within the cell [18]. The hydrazine-pyrrole-2-carboxaldehyde, hydrazinefuran-2-carboxaldehyde, and hydrazine-thiophene-2carboxaldehyde and their phenyl derivatives, as well as their $\mathrm{Co}$ (II), $\mathrm{Cu}$ (II), and $\mathrm{Ni}$ (II) mixed complexes, were synthesized and described [19].

Because of the cooperative effectiveness, if thiosemicarbazone derivatives and transition metal elements are employed together to manufacture a novel medicine, it may have good biological activity. Some thiophene-2-carboxaldehyde thiosemicarbazones and 
their $\mathrm{Ru}(\mathrm{II})$ complexes showed promise against $E$. histolytica in previous research [20].

A recent investigation on the synthesis of novel heterocycles of 2-hydrazinyl-4-methyl-6-phenylpyridine -3-carbonitrile condensed with 5-Methylthiophene-2carbaldehyde was done since several nitrogen and sulphur containing heterocyclic systems demonstrate a wide spectrum of medicinal actions. This could lead to the creation of novel physiologically active molecules. New pyridine compounds and their transition metal complexes, such as $\mathrm{Co}, \mathrm{Ni}$, and $\mathrm{Cu}$, were developed and produced. These compounds were described using a variety of techniques, and their cytotoxic and antibacterial activity was subsequently investigated.

\section{EXPERIMENTAL}

\subsection{Material}

Benzoyl acetone, phosphoryl chloride, sodium ethoxide, triethylamine, hydrazine monohydrochloride, cyanoacetamide, 5-methylthiophene-2-carbaldehyde, Nickel (II) chloride, Cobalt(II) chloride, and Copper (II) chloride were purchased from Sigma Aldrich. All of the other chemicals and solvents were of analytical reagent grade and purchased from a commercial source.

\subsection{Physical measurements}

The elemental analysis $(\mathrm{C}, \mathrm{H}$ and $\mathrm{N})$ was performed on a PerkinElmer $2400 \mathrm{CHN}$ analyzer. Melting points were determined in open capillaries using a G LAB melting apparatus and were reported uncorrected. UVvisible spectra of DMF solutions were recorded on a
UV-210 ELICO spectrometer in the spectral window of 200-800 nm. Infrared spectra (FT-IR) were recorded using a Bruker FT/IR vector 22 spectrometer in the form of $\mathrm{KBr}$ pellets. Proton NMR were recorded in solution state with AVANCE III 500 NMR spectrometer.

\subsection{Synthesis of ligand}

2-hydrazinyl-4-methyl-6-phenylpyridine-3-carbonitrile was synthesized according to earlier reported method [21]. $2.4 \mathrm{~g}(0.01 \mathrm{mmol})$ of it was dissolved in $20 \mathrm{~mL}$ methanol and was added to 5-Methyl thiophene-2carbaldehyde $1 \mathrm{~mL}(0.01 \mathrm{mmol})$ in hot $10 \mathrm{~mL}$ methanolic solution with addition of few drops of concentrated hydrochloric acid. The reaction mixture was placed in a round bottom flask and allowed to reflux for two hours. The brown solid precipitate generated when the reaction mixture was cooled to room temperature was collected by filtration, and the solid product was washed with $\mathrm{MeOH}$ and dried under vacuum. Molecular formulae of ligand $\mathrm{C}_{19} \mathrm{H}_{16} \mathrm{~N}_{4} \mathrm{~S}$; Yield $72.11 \%$; m.p. $192-194^{\circ} \mathrm{C}$; IR $\mathrm{cm}^{-1}$; 3340 (NH), $2235(\mathrm{C} \equiv \mathrm{N}), \quad 1626(\mathrm{C}=\mathrm{N}), \quad 1035($ aromatic $\mathrm{C}-\mathrm{H}) ;{ }^{1} \mathrm{H}-$ NMR; $\delta$ 2.42(s,3H CH 3 pyridine), $\delta 2.26\left(\mathrm{~s}, 3 \mathrm{H} \mathrm{CH}_{3}\right.$ Thiophene), 7.14 (d,1H, Thiophene-H), 6.89(d,1H Thiophene-H), $7.81-(\mathrm{S}, 1 \mathrm{H} \mathrm{CH}) 7.28(\mathrm{~s}, 1 \mathrm{H}, \mathrm{N}-\mathrm{H})$, $7.77 \quad(\mathrm{~s}, 1 \mathrm{H}, \quad \mathrm{Py}-\mathrm{H}), \quad 7.39-7.97 \quad(\mathrm{~m}, 5 \mathrm{H}, \quad$ Ar- $\mathrm{H})$; MS $\mathrm{m} / \mathrm{z}(\%)$ : 334.11; The ligand is synthesized as illustrated in Scheme-1 \& 2, and its mass spectrum was given in fig. 1.

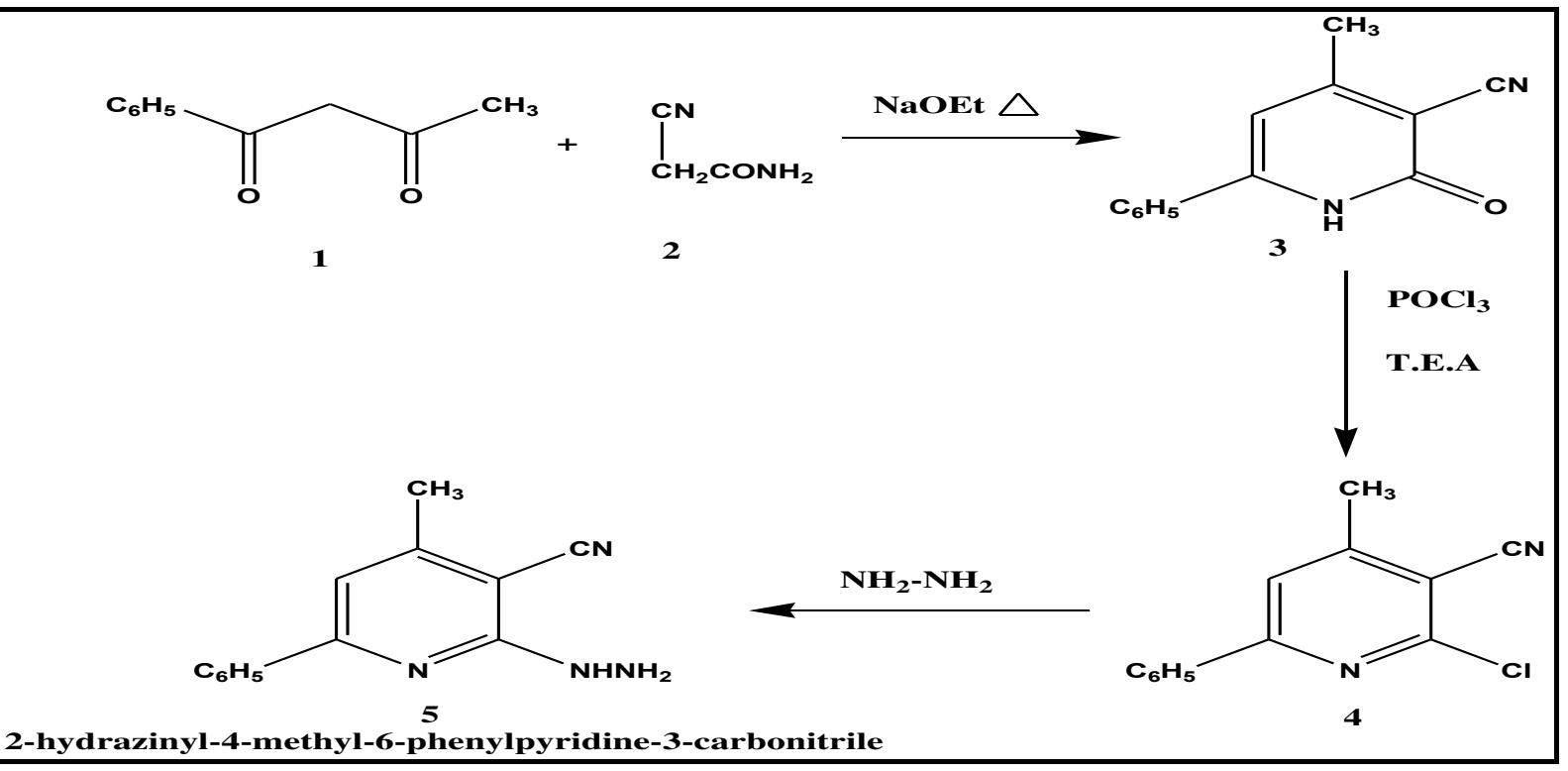

Scheme 1: Synthesis of 2-hydrazinyl-4-methyl-6-phenylpyridine-3-carbonitrile 


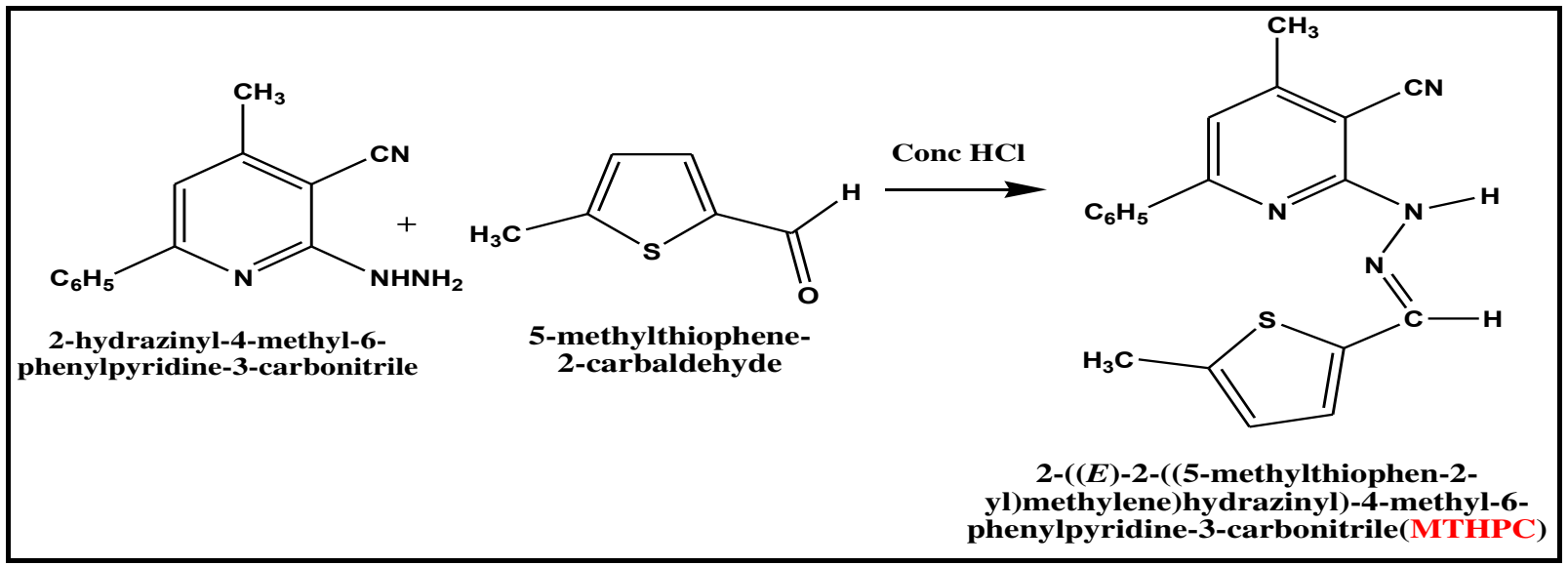

Scheme 2: synthesis of 2-((E)-2-((5-methylthiophen-2-yl)methylene)hydrazinyl)-4-methyl-6-phenylpyridine-3-carbonitrile(MTHPC)

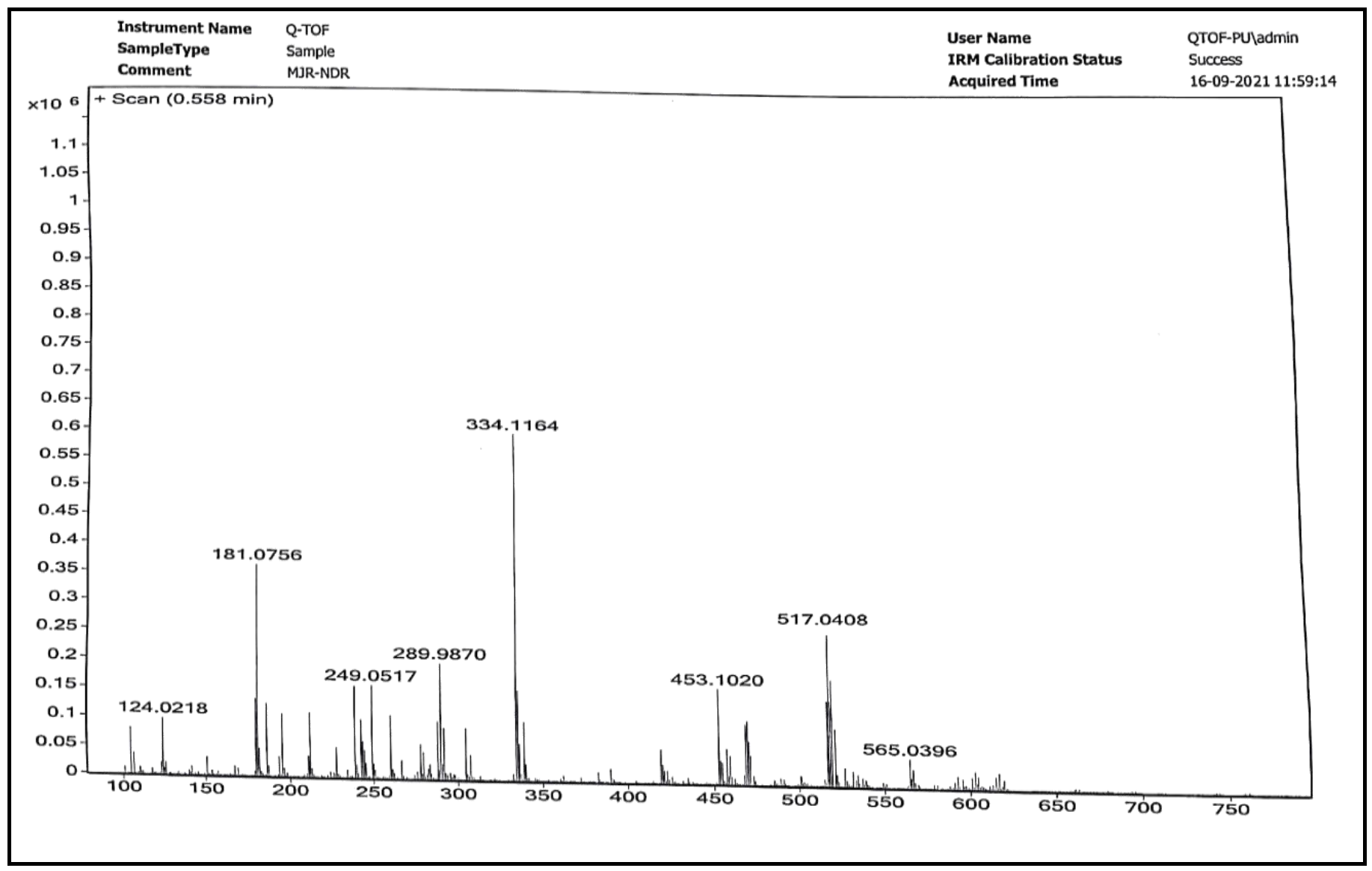

Fig. 1: Mass spectrum of MTHPC Ligand

\subsection{General procedures for the synthesis of complexes}

A hot methanolic solution $(20 \mathrm{~mL})$ of ligand mixture $(3.52 \mathrm{~g} 0.1 \mathrm{~mol})$ was added to a solution of Metal chlorides $(\mathrm{M}=\mathrm{Co}, \mathrm{Ni}$ and $\mathrm{Cu})(0.05 \mathrm{~mol})$ in $\mathrm{H}_{2} \mathrm{O}(50$ $\mathrm{mL}$ ) with addition of $2 \mathrm{ml}$ of $1 \mathrm{M} \mathrm{NaOH}$ solution. The resulting colorless solution was refluxed for $2 \mathrm{~h}$ and then allowed to gently concentrate by evaporation at room temperature for a period of time, resulting in a solid substance that was washed with a tiny amount of $\mathrm{MeOH}$ and dried in the air. Synthesis of metal complex was given in scheme 3. The mass spectrum of Cobalt, Nickel and Copper complexes were given in fig. 2, 3, and 4 respectively. 


\begin{tabular}{|c|c|c|}
\hline $\begin{array}{l}\mathrm{MX}_{2} \cdot \mathrm{XH} \mathrm{H}_{2} \mathrm{O} \\
\text { metal salt }\end{array}$ & $\begin{aligned}+ & \text { MTHPPC } \\
& \text { ligand }\end{aligned}$ & 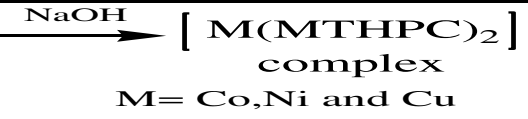 \\
\hline
\end{tabular}

Scheme 3: Synthesis of metal complexes

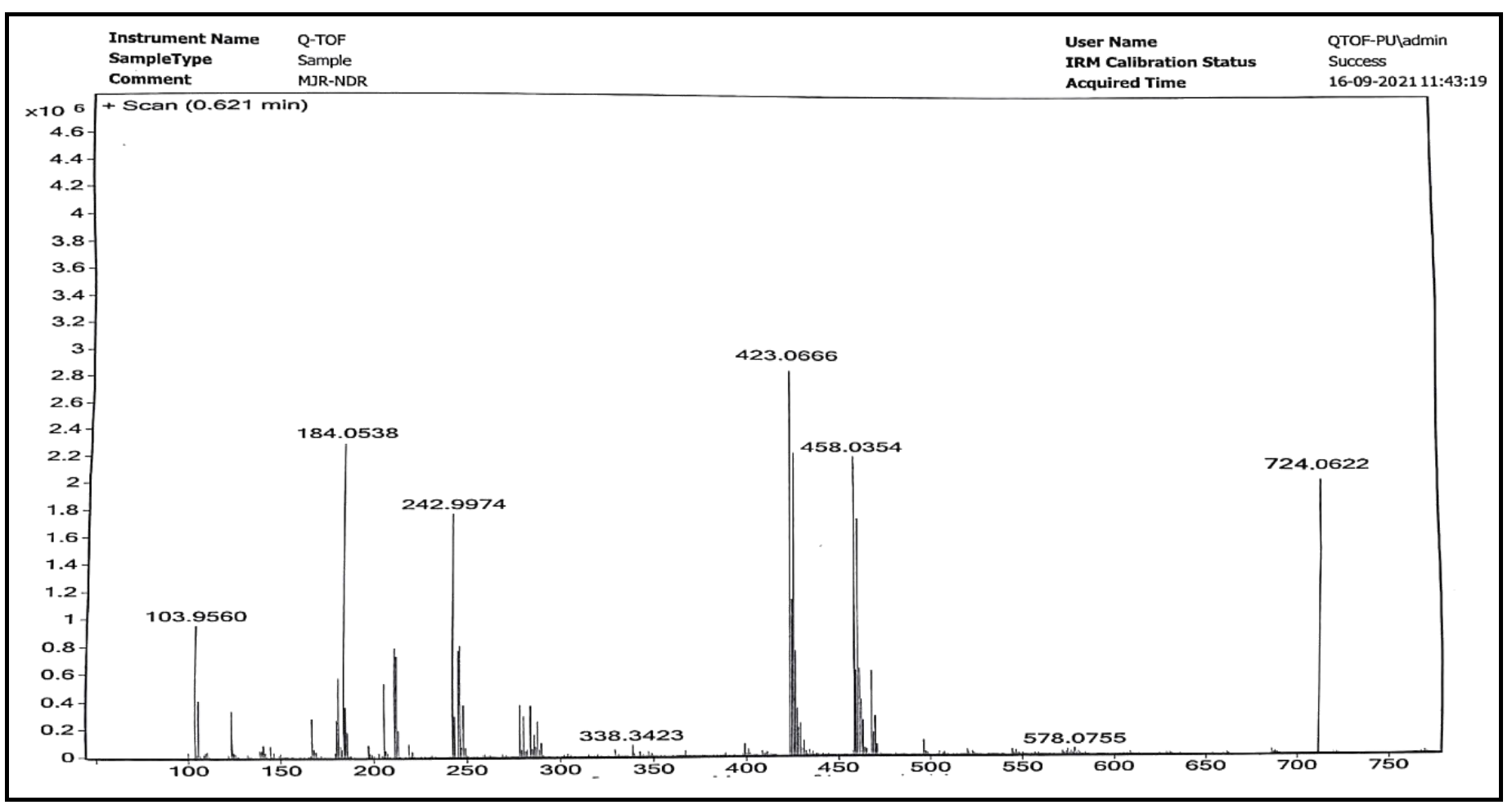

Fig. 2: ESI-Mass spectrum of $\left[\mathrm{Co}\left(\mathrm{MTHPC}_{2}\right]\right.$ Complex

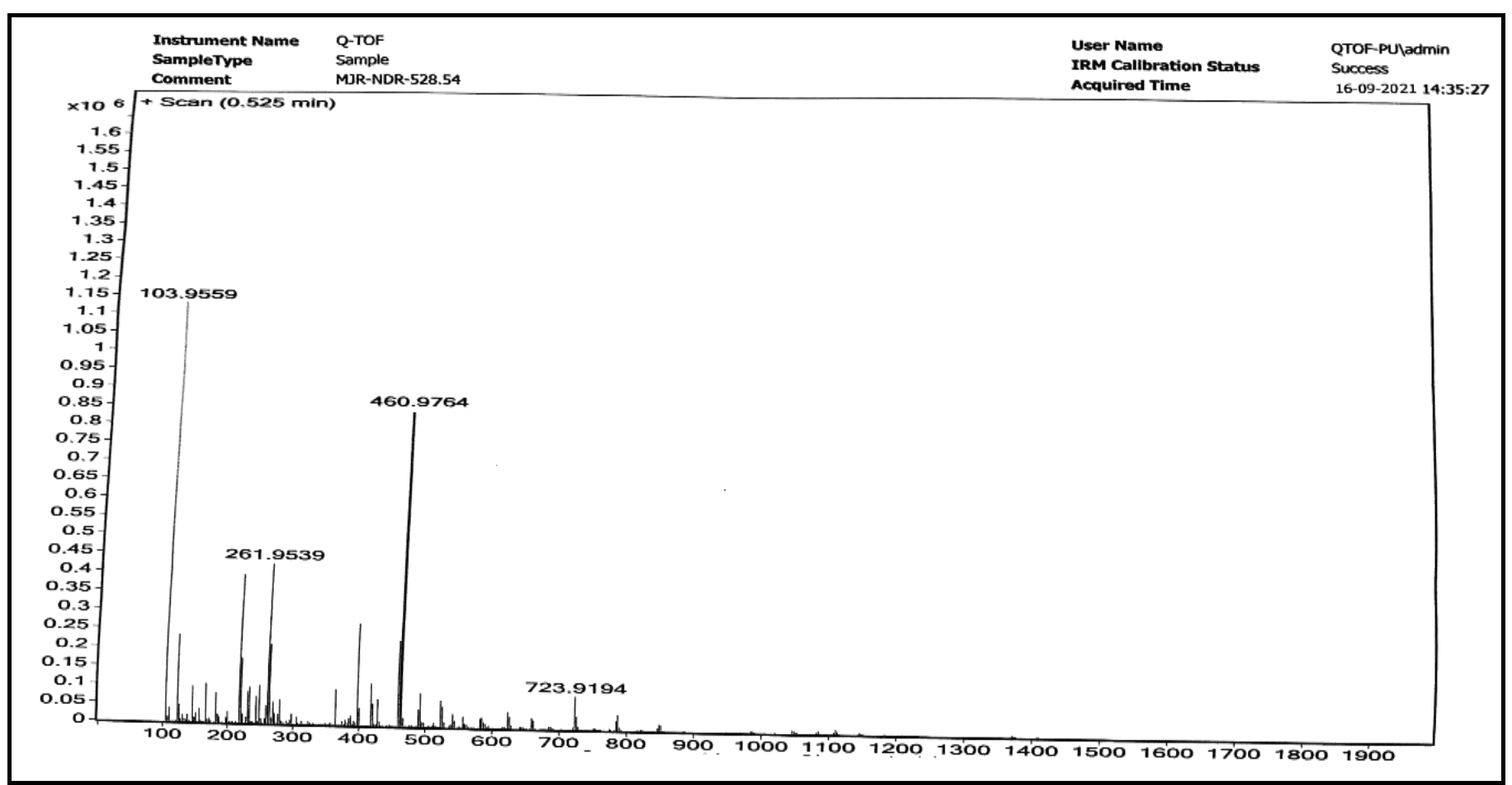

Fig. 3: ESI-Mass spectrum of $\left[\mathrm{Ni}(\mathrm{MTHPC})_{2}\right]$ Complex 


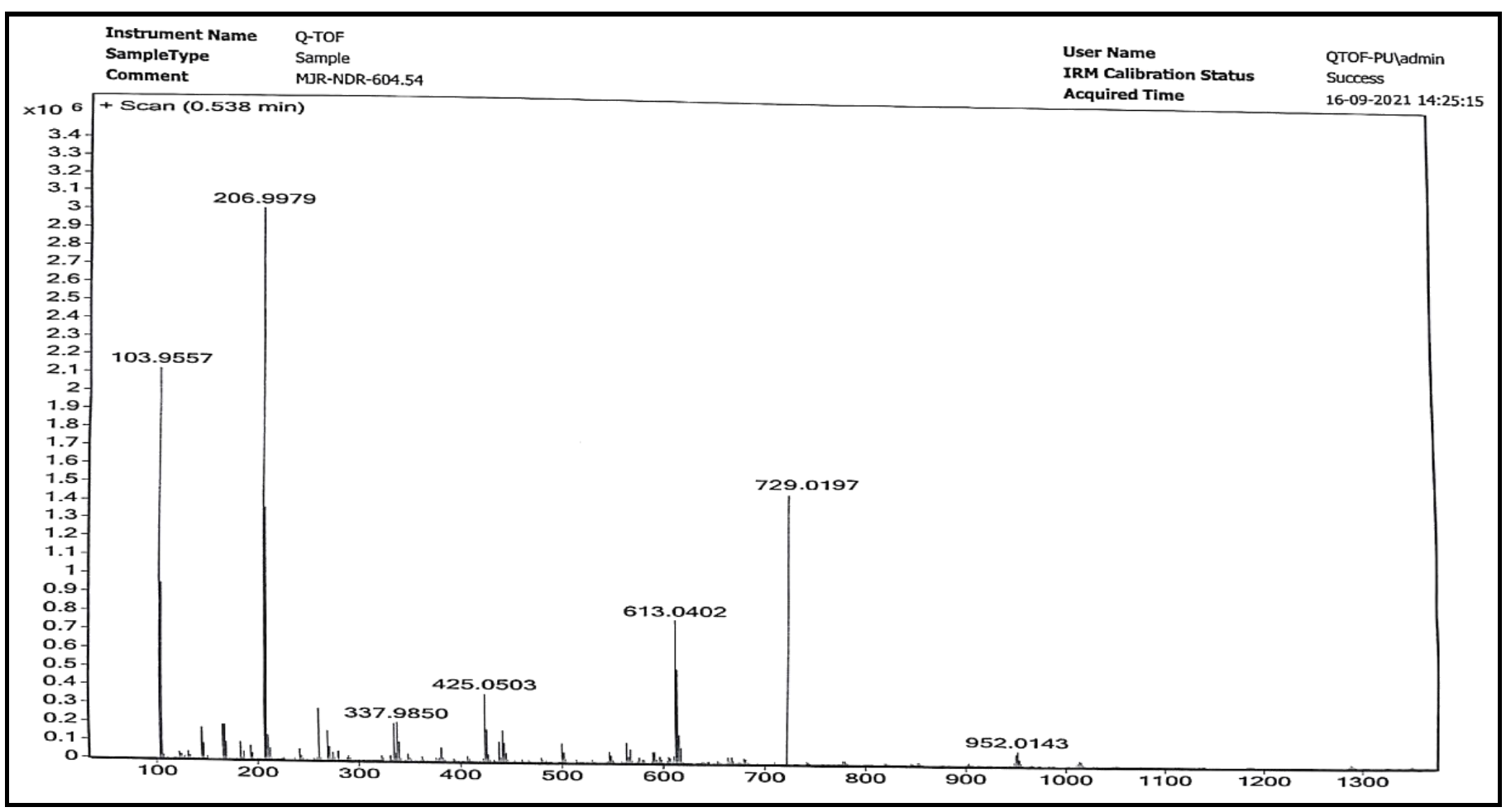

Fig. 4: ESI-Mass spectrum of $\left[\mathrm{Cu}(\mathrm{MTHPC})_{2}\right]$ Complex

\subsection{Determination of cytotoxicity}

Cell lines were grown in the presence of the following Dulbeccos Modified Eagles Medium (DMEM) with supplemented foetal bovine serum and antibiotics for 24 hours at $37^{\circ} \mathrm{C}$ in a humidified atmosphere of $5 \% \mathrm{CO}_{2}$. The cells were planted at a density of $25 \times 103$ cells per well in 96 well plates. The cytotoxicity of varied concentrations of metal complexes (25, 50, 100, 200 and $400 \mu \mathrm{g} / \mathrm{mL}$ ) against human cancer cell lines were examined in MTT assay. MTT is a yellow dye that is reduced into purple crystals in the presence of activity in the mitochondrial succinate dehydrogenase enzyme in viable cells. The $\mathrm{IC}_{50}$ value was determined after a statistical analysis of the cytotoxicity of metal complexes against cancer lines in the presence of MTT.

\subsection{Antibacterial activity}

The antibacterial activity of metal complexes against different pathogenic bacterial strains both Gram -ve bacteria Pseudomonas desmolyticum (NCIM-2028), Escherichia coli (NCIM-5051), and Klebsiella aerogenes (NCIM-2098) and Gram tve Staphylococcus aureus (NCIM-5022) strains (Purchased from National centre for cell science, Pune, India) by Agar well diffusion method. Different concentrations of metal complexes $(100,200,300$ and $400 \mu \mathrm{g} / \mathrm{mL})$ were dispersed in $10 \%$
DMSO solution and while standard antibiotic Ciprofloxacin was used as a positive control in to the wells. The plates were incubated for 24 hours at $37^{\circ} \mathrm{C}$. Following the incubation period, the zone of inhibition around the wells was measured in millimetres. The antibacterial bacterial activity was determined in triplicate, preceded by the bactericidal activity of metal complexes.

\section{RESULTS AND DISCUSSION}

MTHPC, a newly synthesized Schiff base ligand, and its complexes 1-4 were found to be very stable at room temperature. In DMF, they were soluble. Elemental analysis values were in good agreement for complexes with a ratio of $1: 2$. All of them were neutral and nonconducting compounds $\left(\Lambda_{\mathrm{m}}=18.80-26.43 \Omega^{-1} \mathrm{~cm}^{2}\right.$ $\mathrm{mol}^{-1}$ ) [22]. Physico-chemical and analytical data of ligand and its metal complexes were given in Table 1.

\subsection{Electronic spectral bands}

The electronic UV-Visible spectra obtained in DMF solutions, the electronic spectral data of the metal complexes are presented in Table 2. Electronic spectrum of complexes was given in Fig. 5. From the diffuse reflectance spectra it is observed that, the Cobalt complex exhibits a band at $30,303 \mathrm{~cm}^{-1}$, which may be 
assigned to the Charge transition in octahedral geometry of the complex. The region at 14,771 and $16,420 \mathrm{~cm}^{-1}$ refers to the $\mathrm{d}$-d transition. The solid reflectance spectrum of the Nickel complex gives two bands at 28,985 and $36,630 \mathrm{~cm}^{-1}$ wave number regions. The region at 28,985 and $36,630 \mathrm{~cm}^{-1}$ refers to the charge transfer band and $\pi-\rightarrow \pi *$ transition. The reflectance spectrum of Copper chelate consists of a broad, low intensity shoulder band centered at 16,920 and 28,818 $\mathrm{cm}^{-1}$. This assignment is in agreement with the general observation that Copper has $\mathrm{d}-\mathrm{d}$ transitions are normally close in energy. A moderately intense peak observed in the range $28,818 \mathrm{~cm}^{-1}$ is due to ligandmetal charge transfer transition [23-26]. Electronic spectrum of metal complexes is given in fig.5.

Table 1: Physicochemical and analytical data of ligand and their metal complexes

\begin{tabular}{|c|c|c|c|c|c|c|c|}
\hline \multirow[t]{2}{*}{ Compound } & \multirow{2}{*}{$\begin{array}{c}\text { Molecular } \\
\text { Weight Found } \\
\text { (Calculated) }\end{array}$} & \multirow{2}{*}{$\begin{array}{c}\text { Melting } \\
\text { point }\left({ }^{\circ} \mathrm{C}\right)\end{array}$} & \multirow{2}{*}{$\begin{array}{l}\text { Colour } \\
\text { Yield (\%) }\end{array}$} & \multicolumn{3}{|c|}{$\begin{array}{l}\text { Elemental analysis } \\
\text { Found (calculated) }\end{array}$} & \multirow{2}{*}{$\begin{array}{c}\text { Molar } \\
\text { conductivity }\end{array}$} \\
\hline & & & & $\mathrm{C}(\%)$ & $\mathbf{H}(\%)$ & $\mathrm{N}(\%)$ & \\
\hline МТНРС & $\begin{array}{c}334.11 \\
(332.37)\end{array}$ & $192-194$ & $\begin{array}{l}\text { Brown } \\
(72.11)\end{array}$ & $\begin{array}{c}68.47 \\
(68.64)\end{array}$ & $\begin{array}{c}4.78 \\
(4.85)\end{array}$ & $\begin{array}{c}16.75 \\
(16.85)\end{array}$ & - \\
\hline$\left[\mathrm{Co}(\mathrm{MTHPC})_{2}\right]$ & $\begin{array}{c}724.05 \\
(723.67)\end{array}$ & $212-214$ & $\begin{array}{c}\text { Black } \\
(73.48)\end{array}$ & $\begin{array}{c}63.54 \\
(63.05)\end{array}$ & $\begin{array}{c}4.52 \\
(4.45)\end{array}$ & $\begin{array}{c}15.46 \\
(15.48)\end{array}$ & 20.11 \\
\hline$\left[\mathrm{Ni}(\mathrm{MTHPC})_{2}\right]$ & $\begin{array}{c}723.87 \\
(723.43)\end{array}$ & $237-239$ & $\begin{array}{c}\text { Dark Brown } \\
(82.69)\end{array}$ & $\begin{array}{c}63.14 \\
(63.08)\end{array}$ & $\begin{array}{c}4.52 \\
(4.45)\end{array}$ & $\begin{array}{c}15.46 \\
(15.48)\end{array}$ & 18.80 \\
\hline$\left[\mathrm{Cu}(\mathrm{MTHPC})_{2}\right]$ & $\begin{array}{c}729.08 \\
(728.28)\end{array}$ & $254-256$ & $\begin{array}{c}\text { Black } \\
(69.97)\end{array}$ & $\begin{array}{c}62.09 \\
(62.65)\end{array}$ & $\begin{array}{c}4.49 \\
(4.42)\end{array}$ & $\begin{array}{c}15.41 \\
(15.38)\end{array}$ & 26.43 \\
\hline
\end{tabular}

Table 2: UV-Visible spectra of metal complexes with MTHPC ligand

\begin{tabular}{cccc}
\hline Complex & Wavelength $\boldsymbol{\lambda} \mathbf{m a x}(\mathbf{n m})$ & Frequency $\mathbf{( \mathbf { c m } ^ { - 1 } )}$ & Assignment \\
\hline \multirow{2}{*}[\mathbf{Co}(\mathbf{MTHPC})_{2}]{} & 330 & 30,303 & CT transition \\
\cline { 2 - 4 } & 609 & 16,420 & $\mathrm{~d}$-d transition \\
\cline { 2 - 4 } & 677 & 14,771 & $\mathrm{~d}$-d transition \\
\cline { 2 - 4 }$\left[\mathbf{2 N i}(\mathbf{M T H P C})_{2}\right]$ & 273 & 36,630 & $\pi$ - $\rightarrow \pi$ transition \\
\hline \multirow{2}{*}[\mathbf{Cu}(\mathbf{MTHPC})_{2}]{} & 345 & 28,985 & CT transition \\
\cline { 2 - 4 } & 347 & 28,818 & CT transition \\
\hline
\end{tabular}

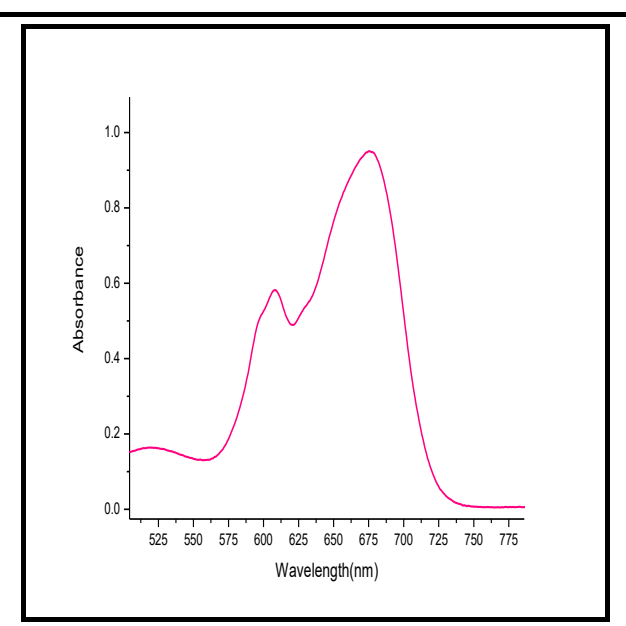

A

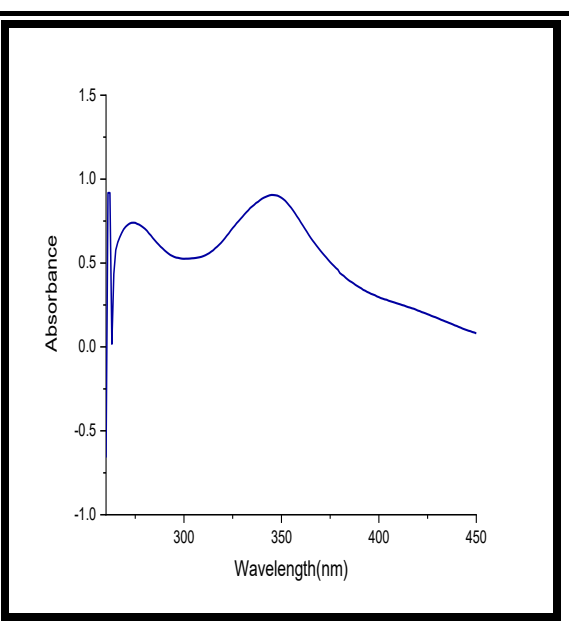

B

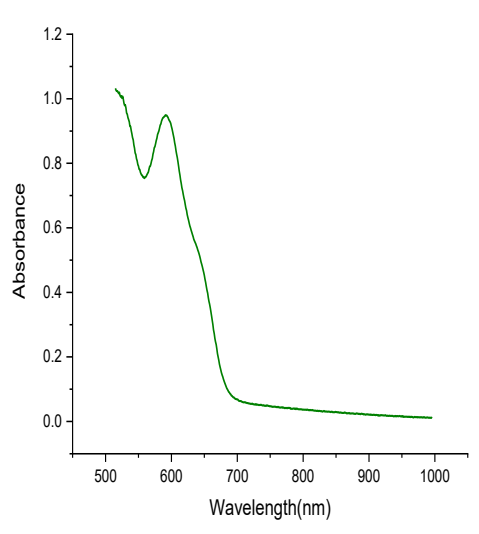

C

Fig. 5: Electronic spectrum of $\left[\mathrm{Co}(\mathrm{MTHPC})_{2}\right]$ Visible region(A); $\left[\mathrm{Ni}(\mathrm{MTHPC})_{2}\right]$ UV region (B); and [Cu $(\mathrm{MTHPC})_{2}$ ] Visible region $(\mathrm{C})$. 


\subsection{IR spectral bands}

The IR data of the MTHPC Schiff base and its complexes are listed in Table 3. The IR spectra of the complexes are compared with those of the free ligand in order to determine the coordination sites that may involve in chelation. There are some guide peaks, in the spectra of the ligand, which are of good help for achieving this goal. The position and/or the intensities of these peaks are expected to be changed upon chelation. These guide peaks are listed in Table 3. Upon comparison it was found that the $v(\mathrm{C}=\mathrm{N})$ of the azomethine stretching vibration is found in the free ligand at $1626 \mathrm{~cm}^{-1}$. This band is shifted to lower 1592 $1575 \mathrm{~cm}^{-1}$ wavenumbers in the complexes indicating the participation of the azomethine nitrogen in coordination $(\mathrm{M}-\mathrm{N})$. New bands are found in the spectra of the complexes in the regions 538-562 and 462-483 which are assigned to $v(\mathrm{M}-\mathrm{N})$ and $v(\mathrm{M}-\mathrm{S})$ stretching vibrations [27-31].

\subsection{ESR analysis of copper complex}

The ESR spectrum of copper (II) complex are recorded in DMF at 300 and $77 \mathrm{~K}$ and the spin Halmiltonian parameters of the complexes are listed in Table 4 (fig.6.) The observed spectral parameters reveals that $g \|>g \perp$ characteristic of an axially elongated octahedral geometry. The $g_{\text {arg }}$ value is less than 2.28 indicating the covalent character of the metal-ligand bond.
Further, it is supported from the fact that the unpaired electrons lies predominantly in the $\mathrm{dx}^{2}-\mathrm{y}^{2}$ orbital. The observed value of $\mathrm{G}$ for copper complex is 2.32, characteristic of mono nuclear configuration which also suggests that the exchange coupling is present and misalignment is appreciable [32-36].

$$
\begin{aligned}
& \mathrm{g}_{\text {avg }}=\frac{\left[\mathrm{g}_{\|}+2 \mathrm{~g}_{\perp}\right]}{3} \\
& \mathrm{G}=\frac{\left[\mathrm{g}_{\|}-2.0023\right]}{\left[\mathrm{g}_{\perp}-2.0023\right]}
\end{aligned}
$$

It has an octahedral geometry, according to the physicochemical and spectral data. It was shown in fig. 7.

\subsection{Cytotoxicity}

On the basis of in-vitro analysis, the cytotoxicity of synthesized ligands and metal complexes against A549 and HepG2 cell line cancer cells was assessed. The ligand and metal complexes were tested against cell lines with Cis-platin as the positive control. As a result, as shown in Tables 5 and 6, the viability assay of cytotoxicity of ligand and metal complexes against A549 and HepG2 cancer cell lines. The decrease in cell viability with increasing metal complex concentrations has shown significant cytotoxicity to accumulate internal cells and higher stress, eventually leading to apoptosis [37-38].

Table 3: IR data of Ligand (MTHPC) and their metal complexes

\begin{tabular}{ccccc}
\hline MTHPC & {$\left[\mathbf{C o}(\mathbf{M T H P C})_{2}\right]$} & {$\left[\mathbf{N i}(\mathbf{M T H P C})_{2}\right]$} & {$\left[\mathbf{C u}(\mathbf{M T H P C})_{2}\right]$} & Assignment \\
\hline 3340 & 3276 & 3284 & 3318 & $\mathrm{~N}-\mathrm{H}$ \\
\hline 2245 & 2239 & 2240 & 2236 & $\mathrm{CN}$ \\
\hline 1626 & 1581 & 1575 & 1592 & $\mathrm{C}==\mathrm{N}$ \\
\hline 1035 & 961 & 987 & 990 & Aromatic CH \\
\hline & 542 & 538 & 562 & $\mathrm{M}-\mathrm{N}$ \\
\hline
\end{tabular}

Table 4: ESR spectral data of Copper Complex

\begin{tabular}{cccccccc|cccc}
\hline Complex & & $g \|$ & $\mathbf{g} \perp$, & $\mathbf{g}_{\text {avg }}$ & $\mathbf{G}$ & $\begin{array}{c}\mathbf{A} \| \mathbf{x} \\
\mathbf{1 0}^{-5}\end{array}$ & $\begin{array}{c}\mathbf{A}^{\perp} \mathbf{x} \\
\mathbf{1 0}^{-5}\end{array}$ & $\mathbf{K} \|$ & $\mathbf{K}^{\perp}$ & $\boldsymbol{\lambda}$ & $\boldsymbol{\alpha}$ \\
\hline$\left[\mathrm{Cu}\left(\mathrm{MTHPC}_{2}\right]\right.$ & $\mathbf{( R T )}$ & 2.14 & 2.07 & 2.09 & 2.03 & - & - & - & - & - & - \\
\hline$\left[\mathrm{Cu}(\mathrm{MTHPC})_{2}\right]$ & $(\mathrm{LNT})$ & 2.09 & 2.04 & 2.05 & 2.32 & - & - & - & - & - & - \\
\hline
\end{tabular}

*RT=Room Temperature; $L N T=$ Liquid Nitrogen temperature

Even though the concentrations were increased, the ligand alone had little effect. The activity increased dramatically as the quantities of metal complexes increased. Nickel complexes had the most activity with
A549 cell lines, whereas Copper complexes had most activity with HepG2 cell lines. The order of cytotoxic effect on A549 cell is $\mathrm{Ni}>\mathrm{Cu}>\mathrm{Co}$ and for HepG2 cell line is $\mathrm{Cu}>\mathrm{Ni}>\mathrm{Co}$. It was shown in fig. 8 \& 9 . 
Table 5: Cytotoxicity of Ligand and metal complexes with Lung cancer cell lines A549

\begin{tabular}{ccccccc}
\hline \multicolumn{7}{c}{ A549 cell line } \\
\hline \multicolumn{7}{c}{ Concentrations $(\boldsymbol{\mu g} / \mathbf{m L})$} \\
\hline Standard (Cis-Platin) & 25 & 50 & 100 & 200 & 400 & IC $_{50}$ \\
\hline MTHPC & 49.09 & - & - & - & - & - \\
\hline$\left[\mathbf{C o}(\mathbf{M T H P C})_{2}\right]$ & 96.46 & 91.45 & 86.24 & 82.30 & 78.66 & - \\
\hline$\left[\mathbf{N i}(\mathbf{M T H P C})_{2}\right]$ & 95.12 & 81.85 & 73.82 & 61.54 & 48.70 & 376 \\
\hline$\left[\mathbf{C u}(\mathbf{M T H P C})_{2}\right]$ & 92.06 & 78.56 & 69.76 & 56.92 & 45.24 & 320 \\
\hline & 91.48 & 80.26 & 72.18 & 60.46 & 47.86 & 365 \\
\hline
\end{tabular}

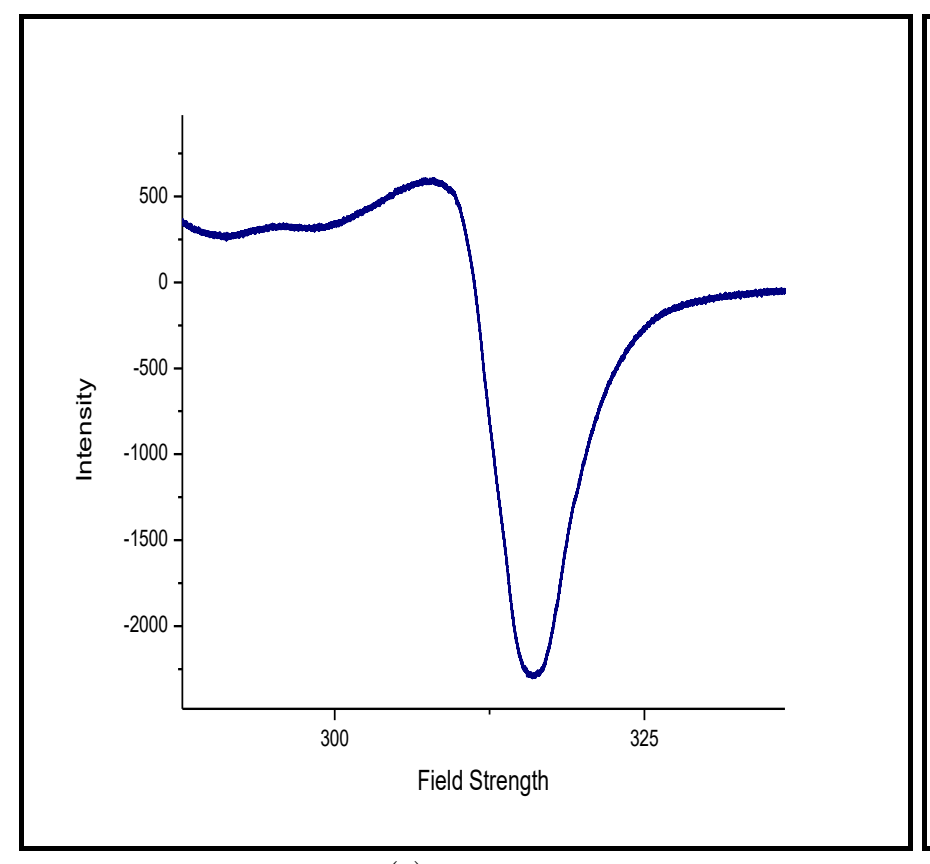

(a)

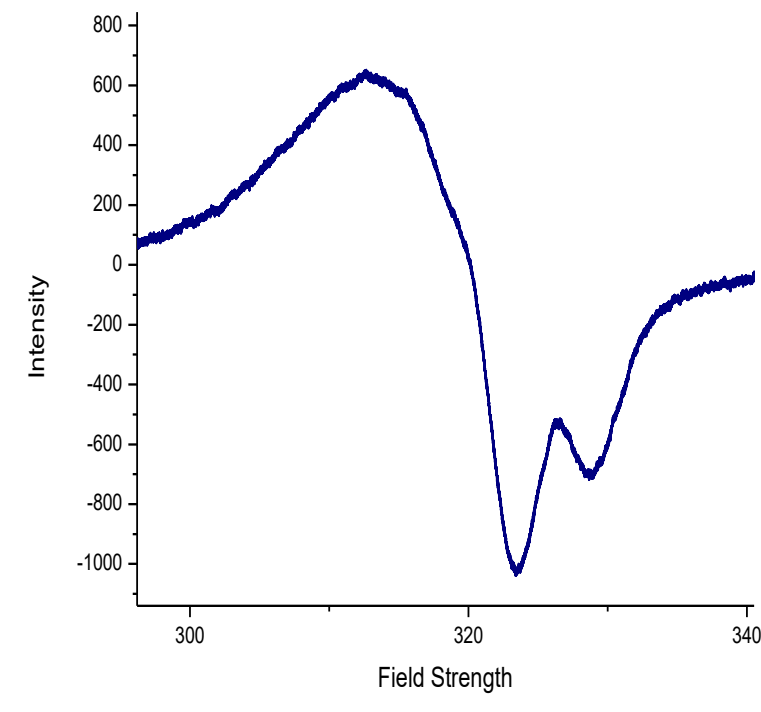

(b)

Fig. 6: ESR spectra of Copper complex recorded at LNT (a) and RT (b)

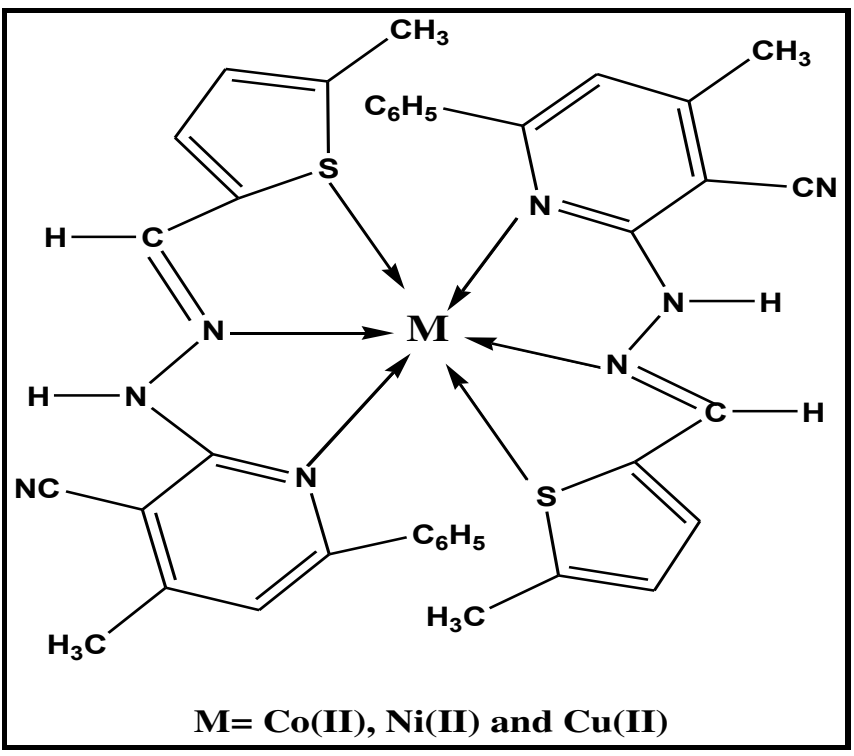

Fig. 7: Proposed structure of metal complexes

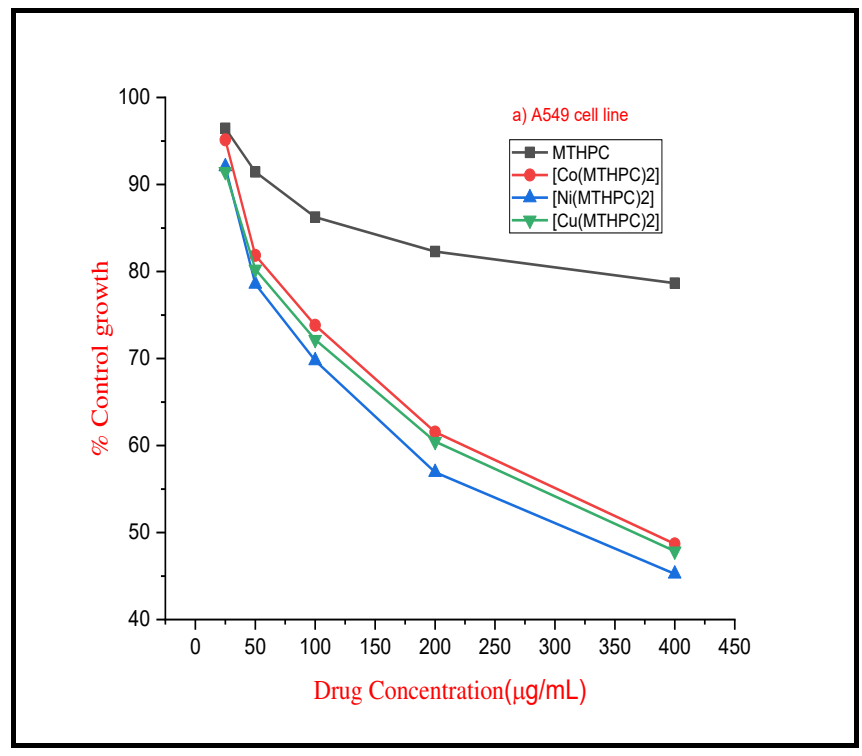

Fig. 8: Graphical representation of metal complexes with cytotoxicity effect on A549 cell lines 
Table 6: Cytotoxicity of Ligand and metal complexes with Lung cancer cell lines HepG2

\begin{tabular}{ccccccc}
\hline \multicolumn{7}{c}{ HepG2 cell line } \\
\hline & Concentrations $(\boldsymbol{\mu g} / \mathbf{m L})$ & & & & \\
\hline & 25 & 50 & 100 & 200 & 400 & $\mathrm{IC}_{50}$ \\
\hline Standard (Cis-Platin) & 54.48 & - & - & - & - & - \\
\hline $\mathbf{M T H P C}$ & 97.38 & 92.59 & 87.46 & 80.10 & 76.42 & - \\
\hline$\left[\mathbf{C o}(\mathbf{M T H P C})_{2}\right]$ & 96.46 & 80.88 & 72.56 & 63.28 & 46.08 & 354 \\
\hline$\left[\mathbf{N i}(\mathbf{M T H P C})_{2}\right]$ & 95.82 & 80.62 & 73.98 & 60.54 & 45.26 & 335 \\
\hline$\left[\mathbf{C u}(\mathbf{M T H P C})_{2}\right]$ & 92.75 & 79.16 & 70.82 & 59.16 & 42.54 & 310 \\
\hline
\end{tabular}

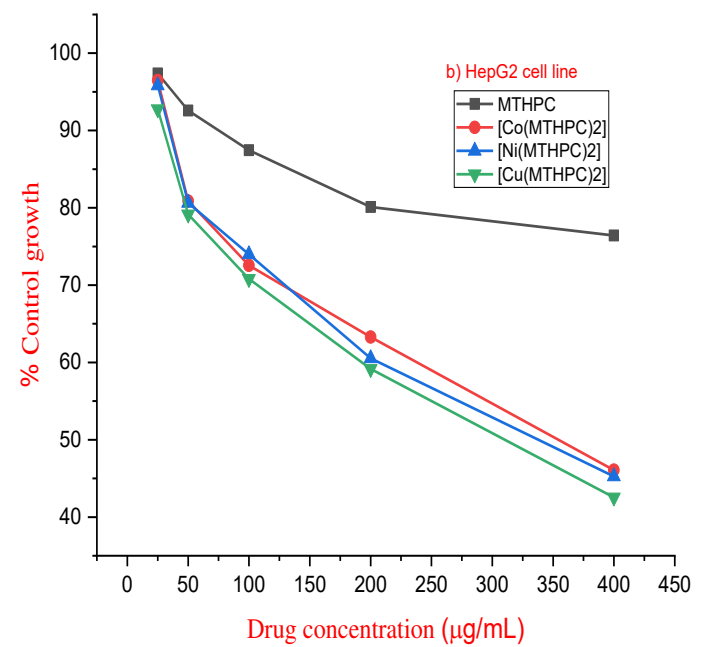

Fig. 9: Graphical representation of metal complexes with cytotoxicity effect on HepG2 cell lines

\subsection{Antibacterial activity}

The antibacterial activity of the ligand MTHPC and its metal (II) complexes was investigated. The zone of inhibition was measured in millimetres, and the values of the substances studied are listed in Table 7. In testing of antibacterial activity of these compounds, we used more than one test organism. All of the tested compounds showed a remarkable biological activity against different types of Gram-positive and Gramnegative bacteria. On comparing the biological activity of the Ligand (MTHPC) and its metal complexes with the standard Ciprofloxacin, the following results are obtained.

It is obvious from the results that the metal complexes have greater antibacterial action than the free ligand MTHPC. The biological activity of the complexes follow the order $\mathrm{Ni}>\mathrm{Cu}>\mathrm{Co}$ Also, the data in Table 7. This is most likely owing to the complexes increased lipophilicity. The increased activity of metal (II) complexes can be explained using Overton's concept and Chelation theory [39-42]. One possible explanation for the observed increased activity after chelation is that the positive charge of the metal in the chelated complex is partially shared with the ligand donor atoms, resulting in electron delocalization throughout the chelate ring. This, in turn, increases the lipophilicity of the metal chelate and facilitates its permeation through the lipid layers of bacterial membranes. Antibacterial activity at various concentrations of the Ligand and their complexes with different pathogenic strains were given in Table 7.

Table 7: Antibacterial activity of Ligand and Metal complexes with different pathogenic strains

\begin{tabular}{|c|c|c|c|c|c|}
\hline \multicolumn{6}{|c|}{ Treatment } \\
\hline Sample & Concentration $(\mu \mathrm{g} / \mathrm{mL})$ & S. aureus & E. coli & P. desmolyticum & K. aerogenes \\
\hline Ciprofloxacin & 10 & 14.10 & 11.45 & 11.52 & 12.06 \\
\hline МТНРС & 100 & 0.98 & 1.06 & 0.82 & 1.02 \\
\hline \multirow{4}{*}[\mathrm{Co}(\mathrm{MTHPC})_{2}]{} & 100 & 2.32 & 2.64 & 2.04 & 2.52 \\
\hline & 200 & 3.54 & 3.68 & 3.26 & 3.48 \\
\hline & 300 & 4.46 & 4.82 & 3.98 & 4.24 \\
\hline & 400 & 6.42 & 6.88 & 6.05 & 6.76 \\
\hline \multirow{4}{*}[\mathrm{Ni}(\mathrm{MTHPC})_{2}]{} & 100 & 2.74 & 2.82 & 2.16 & 2.94 \\
\hline & 200 & 4.36 & 3.91 & 3.83 & 4.02 \\
\hline & 300 & 5.54 & 5.64 & 4.14 & 5.46 \\
\hline & 400 & 7.92 & 8.16 & 7.83 & 7.84 \\
\hline \multirow{4}{*}[\mathrm{Cu}(\mathrm{MTHPC})_{2}]{} & 100 & 2.48 & 2.51 & 2.26 & 2.64 \\
\hline & 200 & 3.94 & 3.75 & 3.74 & 3.93 \\
\hline & 300 & 4.82 & 5.18 & 4.42 & 5.28 \\
\hline & 400 & 7.16 & 7.28 & 7.64 & 7.56 \\
\hline
\end{tabular}




\section{CONCLUSION}

A novel pyridine derivative of the ligand [MTHPC] and their transition metal complexes (where $\mathrm{M}=\mathrm{Cu}$, Co, and $\mathrm{Ni}$ ) have been synthesized and described. The complexes' stoichiometry and composition were determined using elemental, conductivity, and mass spectrometry studies. FT-IR, UV-Vis, $1 \mathrm{H}$ NMR, and ESR spectrum data were used to corroborate the bonding properties of the aforesaid ligand and metal complexes. Copper complex ESR values show that the complex has an octahedral geometry, based on the observations. Increased metal complex concentrations have caused significant cytotoxicity, resulting in the buildup of internal cells and increased stress, eventually leading to apoptosis. The cytotoxicity of metal complexes is higher than that of free ligand. For A549 cell lines, Nickel complexes had the maximum activity, whereas Copper complexes had the highest activity for HepG2 cell lines. The ligand (MTHPC) and its metal complexes have antibacterial activity in vitro, indicating that the complexes are more effective than the free ligand. Copper and Cobalt complexes have moderate antibacterial activity, but Nickel complexes have significant antibacterial activity.

\section{ACKNOWLEDGEMENTS}

Author is thankful to National Centre for Cell Science, Pune for providing Cancer Cell lines and SAIF centres KUD, Dharwad, and IIT Bombay for providing instrument facility for ESR, NMR and Mass analysis. The authors are also thankful to G. John, MAHE, Manipal University, for his cooperation in research work.

\section{Conflict of interest}

The authors have no conflicts of interest regarding this investigation.

\section{REFERENCES}

1. Paronikyan EG, Noravyan AS, Dzhagatspany IA, Nazaryan IM, Paronikyan RG. Pharm. Chem. J., 2002; 36:465-467.

2. Patel NB, Agravat SN, Shaikh FM. Med. Chem. Res., 2011; 20:1033-1041.

3. Patel NB, Agravat SN. Chem. Heterocycl. Compd., 2009; 45:1343-1353.

4. Srivastava A, Pandeya SN, Int. J. Curr.Pharm. Rev. Res., $2011 ; 24: 5-8$.
5. Bernardino AMR, De Azevedo AR, Pinheiro LCD, Borges JC, Carvalho VL, Miranda MD, De Meneses MDF, Nascimento M, Ferreira D, Rebello MA. Med. Chem. Res., 2007; 16:352-369.

6. Tucker TJ, Sisko JT, Tynebor RM, Williams TM, Felock PJ, Flynn JA, Lai M, Liang Y, McGaughey G, Liu M. J. Med. Chem., 2008;51:6503-6511.

7. Comins DL, Saha JK. J. Org. Chem., 1996; 61:9623.

8. Comins DL, Nolan JM. Org. Lett., 2001; 3:4225.

9. You ZL, Zhu HL, Liu WS. Chemie. 2004; 630(11):1617-1622.

10. Golcu A, Tumer M, Demirelli H, Wheatley RA. Inorganica Chimica Acta., 2005; 358(6):1785-1797.

11. Morgan SM, El-Sonbati A, Eissa H. Journal of Molecular Liquids, 2017; 240:752-776.

12. Asraf MA, Younus HA, Ezugwu CI, Zakaria C, Mehta A, Verpoort F. Catalysis Science \& Technology., 2016; 6(12):4271-4282.

13. Asraf MA, Younus HA, Yusubov M, Verpoort F. Catalysis Science \& Technology., 2015; 5(11):4901-4925.

14. Mahmoud WH, Mohamed GG, El-Sayed OY. Applied Organometallic Chemistry, 2018; 32(2):e4051.

15. Hosseini-Yazdi SA, et al. Polyhedron, 2014; 80:41-46.

16. Anacona J, Santaella J. Spectrochimica Acta Part A:Molecular and Biomolecular Spectroscopy. 2013; 115:800804.

17. Garnovskii A, Nivorozhkin AL, Minkin VI. Coordination Chemistry Reviews. 1993; 126:1-69.

18. Jayakumar K, et al. Polyhedron, 2014; 75:50-56.

19. Chohan ZH, Sherazi SKA. J. Chem. Soc. Pak. 1997; 19:196.

20. Bharti NS, Gonzalez Garza MT, Cruz Vega DE, Garza JC, Saleem K, Naqvi F, Azam A. Bioorg. Med. Chem. Lett., 2001; 11:2675-2678.

21. Rahman Al-Issa S A. Molecules, 2012; 17:10902-10915.

22. Geary WJ. Coord. Chem. Rev., 1971; 7:81-122.

23. Lever ABP. Inorganic Electronic Spectroscopy, Elsevier Publishing Company, Amsterdam, 1968.

24. Nakamoto K, Infrared Spectra of Inorganic and Coordination Compounds, 4th. edition, Wiley Interscience, New York, 1986.

25. Reddy PM, Rohini R, Ravi Krishna E, Hu A, Ravinder V, Int. J. Mol. Sci., 2012;13(4):4982- 4992.

26. Silverstein RM, Bassler CG, Morrill TC. Spectrometric identification of organic compounds, 3 Edition, Wiley and Sons, USA, 1974. 
27. Badwaik VB, Deshmukh RD, Aswar AS. Synthesis, Russian J. of Coordination Chem., 2008; 35(4):247-252.

28. Çakir S, Biçer E. J. Iran. Chem. Soc., 2010; 7(2):394404.

29. Avram M, Mateescu Gh D. Spectroscopia în infraroşu Aplicaţii în chimia organică. Ed. Tehnică, Bucureşti, 1966.

30. Gupta LK, Chandra S. Transition Met. Chem., 2006; 31(3):368-373.

31. Florina $C$, Luminiţa $P$, Luminita $M$, Mariana $C$. Farmacia., 2015; 63(1):86-92.

32. Hathaway BJ, Billing DE. Coord. Chem. Rev., 1970; 5:143-207.

33. Ahuja IS, Tripathi S. Spectrochim. Acta., 1991; 47A:637641.

34. Bindu P, Kurup MRP, Satyakeerty TR. Polyhedron, 1998; 18:321-331.
35. Singh OI, Damayanti M, Singh NR, Singh RKH, Mohapatra M, Kadam RM. Polyhedron, 2005; 24:909916.

36. Vinod PS. Spectrochimica Acta Part A., 2008; 71:17-22.

37. Liji J, Dasan A, Selwin JR, Hubert JI. Journal of Molecular Structure, 2019; 1198:126934.

38. Liji J, Selwin JR, Hubert JI, Journal of Coordination Chemistry, 2019; 72(16):2669-2687.

39. Shakeela Y, Sajjad HS, Muhammad SA, Zahid HC. Journal Of Enzyme Inhibition and Medicinal Chemistry, 2017; 32(1):106-112.

40. Dipta S, Faruk HM, Kudrat-E-Zahan M, Masuqul HM, Zamir R, Ali AM. Journal of Materials Science Research and Reviews, 2020; 5(2):15-25.

41. Shailendra, Neelam B, Fehmida N, Amir A. Bioorganic \& Medicinal Chemistry Letters, 2003; 13(4):689-692.

42. Gehad G, Mohamed, Omar MM, Ahmed, Hindy MM. Spectrochimica Acta Part A, 2005; 62:1140-1150. 